\title{
MANIFESTASI RINDU KEPADA IBU SEBAGAI TERAPI SENI
}

Oleh: Bernadetha Dwi Puspitasari

Institusi: Institut Seni Indonesia Yogyakarta

\begin{abstract}
ABSTRAK
Kesedihan itu mungkin adalah reaksi normal, sama ketika seseorang mengalami rasa "kehilangan" seseorang yang dicintai, terlebih ketika kehilangan karena kematian ibu. Rasa kehilangan ini merupakan situasi yang aktual dan potensial yang dapat dialami oleh semua orang di dunia ini ketika berpisah dengan seseorang yang sebelumnya ada menjadi tidak ada. Keseluruhan rasa kehilangan sangat berdampak pada emosi hingga membutuhkan sebuah cara melalui 'seni' untuk mengurangi perasaan sedih serta rindu kepada ibu dalam kehidupan sehari-hari sebagai terapi.

Terapi seni sebagai solusi yang diyakini memiliki kemampuan untuk menerjemahkan isi pikiran, mencatat dan menyampaikan berbagai tingkatan emosi, dari rasa nyaman, hingga kesedihan yang terdalam, dari mulai kejadian yang membahagiakan hingga trauma. Terapi seni sangat bermanfaat sebagai "katup" pelepasan impuls-impuls memori positif maupun negatif yang sebelumnya terpendam. Selama proses kreativitas penciptaan karya seni, semua emosi dan pikiran yang mengendap akan tereksternalisasi atau tersalurkan. Semua emosi dan pikiran tersebut pada akhirnya akan menjadi jelas akar permasalahannya, karena terbaca dalam simbol-simbol dan bentuk yang ada dalam pikiran yang terdapat pada karya. Kadang kala dibentuk dengan sadar atau tidak sadar dan memiliki makna terdalam yang berhubungan langsung dengan akar pikiran dan emosi si pembuatnya.
\end{abstract}

Kata kunci: Manifestasi, ibu, rindu, terapi seni, momori positif dan negatif

ABSTRACT

Grief are normal reaction, same as when we lose someone we love, especially when we lose our mother. Our loss were actual situation and potentially can be experienced by all of people in the world when we separated with someone who previously existed to be non-existed. The overall sense of loss, greatly affect to emotions and needs a way through art to reduce the feelings of sadness and longing for the mother in everyday life as a therapy.

Art therapy as a solution that believes has the ability to translate contents of the mind, record and convey various levels of emotions, from comfort, to the deepest sadness, from the happiness to the trauma. Art therapy are helpful as a valve to release positive memory impulse or negative which are hidden before. During the creative process of creating works of arts, all of the emotions, thoughts, which are hidden before will be externalized or channeled. All of emotions and thoughts finally will be eventually become clear the root of the problem, because it is read the symbols and forms that exist in the work of art. Sometimes it formed consciously or not and has the deepest meaning that is directly related to the roots of creator's mind and emotions.

Keywords: Manifestions, mother, longing, art therapy, positive and negative memories.

\section{PENDAHULUAN}

Ibu merupakan orang tua yang paling dekat dengan anaknya, namun ketika seseorang dihadapkan pada suatu peristiwa yang tidak diinginkan dalam hidupnya pasti akan terasa berat untuk menerima. Seperti pada peristiwa kematian ibu yang 
secara otomatis memisahkan hubungan komunikasi antara anak dan ibu, tentunya sulit untuk diterima siapapun karena tidak ada satu orangpun yang benar-benar siap ketika harus kehilangan ibu yang dicintainya.

Intensitas dan lamanya respon berbagai perasaan tersebut memang tergantung pada penyebab kesedihannya, tergantung pada kemampuan mengalami kesedihan dan sistem lingkungan yang diterimanya. Pada kasus ini, kematian ibu seniman disebabkan oleh penyakit Leukimia (kanker darah) dan dibutuhkan waktu yang lama untuk melupakan peristiwa duka yang dialami selama ibu sakit hingga pada detik kematian ibu. Walau hingga saat ini perasaan sedih masih dirasakan, beberapa upaya telah dicoba untuk dapat mengurangi dampak dari rasa kehilangan tersebut.

\section{KONSEP PENCIPTAAN}

\section{A. Latar Belakang}

Peristiwa kematian bukan hanya melibatkan seseorang yang meninggal dunia tapi juga berdampak bagi orang terdekat yang ditinggalkan, seperti yang seniman alami ataupun setiap individu yang mengalami. Tetapi melalui proses waktu, umumnya akan berangsur-angsur pulih ke keadaan semula. Tetapi dampak kehilangan ini bisa beragam pada setiap individu. Faktor emosi dan usia juga mempengaruhi proses duka dari masing-masing individu. Kehilanggan memunculkan perasaan terancam pada perkembangan hidup selanjutnya bagi yang kehilangan.

Seniman menciptakan karya seni sebagai manifestasi rasa rindu kepada ibu dan ingin mentransfer atau menghadirkan sosok ibu dalam karya seni, dengan mengangkat simbol-simbol yang mewakili rasa tindu terhadap sosok ibu sebagai ungkapan rasa yang mendalam kepada ibu. Selain sebagai self therapy, proses ini juga dapat membantu untuk melihat ibu dalam fisik karya seni, hingga ibu tidak lagi hanya ada di dalam pikiran seniman, namun dapat hadir secara nyata dalam bentuk karya seni, dan orang lain dapat melihat representasi ibu, serta mengetahui makna seorang "ibu” bagi seniman, dipercaya bahwa proses terapi seni ini dapat membantu untuk lebih positif dalam hal pikiran maupun sikap dikemudian hari. Maka dirumuskan beberapa pertanyaan sebagai berikut: 
1. Bagaimana caranya menggunakan perumpamaan yang tepat agar makna rasa rindu terhadap ibu dapat digambarkan atau divisualisasikan

2. Simbol-simbol apa saja yang dipakai untuk menciptakan konsep kerinduan terhadap ibu melalui terapi seni?

3. Teknik apa yang tepat untuk menggambarkan emosi atas kerinduan seniman kepada ibu?

\section{B. Teori dan Metode}

\section{Teori}

\section{Grief}

Menurut Santrock (2004: 272) dukacita (grief) adalah kelumpuhan emosional, tidak percaya, kecemasan akan berpisah, putus asa, sedih, dan kesepian yang menyertai disaat kita kehilangan orang yang kita cintai. Selain itu masih banyak teori psikologi lain yang seniman temukan yang menjelaskan unsur-unsur emosional seseorang tentang alam pikiran dan rasa.

Berdasarkan penjelasan di atas teori grief ditemukan bahwa peristiwa kematian dapat menyebabkan grief, dan dapat dialami oleh siapa saja di dunia ini. Grief tidak boleh dibiarkan berlarut-larut karena jika berkepanjangan dapat menimbulkan stres bahkan depresi sehingga seseorang tidak dapat melanjutkan perkembangan hidupnya, terutama dalam perkembangan emosional dan sosial mereka. Rasa rindu kepada ibu merupakan masalah penting yang perlu diangkat menjadi penelitian untuk dijadikan self treatment melalui terapi seni (bagi diri seniman sendiri).

Stewart, dkk (1988: 605) mengemukakan bahwa grief merupakan perasaan sedih ketika orang yang dicintai meninggal. Menurut Parkes and Weiss, 1983 (dalam Stewart, dkk, 1988: 605), dukacita merupakan trauma paling berat yang pernah dirasakan oleh kebanyakan orang. Berdasarkan definisi-definisi tersebut maka grief dapat diartikan sebagai respon emosional terhadap kehilangan seseorang melalui kematian, yang merupakan penderitaan emosional yang kuat serta mendalam dan dapat diekspresikan dengan berbagai cara. Kehilangan tersebut dapat terjadi pada 
seseorang yang dicintai atau memiliki ikatan emosional yang kuat dengan orang yang ditinggalkan.

Satu pandangan menyebutkan bahwa seseorang akan melewati 3 fase duka cita setelah kehilangan seseorang yang kita cintai: shock, putus asa, dan pulih kembali menurut Averill 1968 (dalam Santrock, 2004: halaman 272). Berdasarkan J. T. Brown \& Stoudemire, 1983; R. Schulz, 1978 (dalam Papalia, dkk 2008: halaman 957) proses penyelesaian duka (grief work), penyelesaian masalah psikologis yang dihubungkan dengan duka, biasanya mengikuti jalur berikut, walaupun sebagaimana tahap Kubler-Ross (dalam Santrock, 2004: 272), tahapan tersebut dapat bervariasi.

Papalia (2008: 957) mengemukakan bahwa tiga tahap yang dapat dilalui seseorang sehubungan dengan grief yang dialaminya, yaitu:

a. Shock dan tidak percaya.

Setelah peristiwa kematian terjadi, seseorang yang ditinggalkan akan mengalami kehilangan dan kebingungan. Ketika ia menyadari bahwa ia telah ditinggalkan, ia akan mengalami perasaan sedih yang meluapluap serta berkali-kali menangis.

b. Asik dengan kenangan mereka yang meninggal

Pada tahap ini, seseorang yang ditinggalkan berusaha menerima kematian yang terjadi namun tetap tidak bisa menerima dengan sepenuhnya. Tahap ini berlangsung selama enam bulan atau lebih.

c. Resolusi

Tahap ini muncul ketika seseorang yang berduka mulai mencurahkan kembali perhatiannya pada aktivitas sehari-hari. Kenangan akan seseorang yang telah meninggal menimbulkan perasaan cinta yang bertabur duka.

\section{Terapi seni}

Terapi Seni (Art Therapy) menurut Bristish Association of Art Therapish adalah sebagai bentuk psikoterapi yang menggunakan seni sebagai bentuk komunikasi dan ekspresi. Sedangkan menurut Malchiodi (1998) terapi seni adalah bentuk terapi yang membantu individu dari segala usia untuk menciptakan makna dan mencapai visi (kesehatan jiwa). Pada terapi seni 
yang terpenting bukanlah hasil akhir proses berkarya, tetapi proses berkeseniannya itu sendiri.

Sementara itu Menurut ahli psikologi klinis Monty Prawitatirta Satiadarma dari Universitas Tarumanegara Jakarta, menyebutkan bahwa menjaga keseimbangan hidup memerlukan saluran. Terapi seni merupakan salah satu saluran dan merupakan bagian penting untuk pemeliharaan kesehatan emosi dan kejiwaan. Monty Prawitatirta Satiadarma juga mengatakan menato kulit bukan bagian dari terapi seni, tetapi metode pengalihan rasa sakit dengan memindahkan layar proyeksi ke dalam kanvas tubuh seseorang. Secara umum seni mengutamakan unsur keindahan dan memiliki arah efektif bagi kejiwaan dan seni menjadi jembatan antara dunia luar dan dunia dalam (batin). Pada diskusi Indonesian Street Art Database juli 2015 dihadirkan dua narasumber yakni Khairani Barokka dan Hana Alfikih yang membicaran terapi seni dan kaitannya dengan kompatibilitas. Mereka memaparkan bahwa terapi seni mengubah diri seseorang dari kurang baik menjadi lebih baik.

\section{Psikologi dalam Seni}

Psikologi berasal dari kata Yunani "Psyche" yang artinya jiwa, "Logos" berarti ilmu pengetahuan. Jadi secara etimologi psikologi berarti : "adalah ilmu pengetahuan yang mempelajari tingkah laku manusia, baik sebagai individu maupun dalam hubungannya dengan lingkungannya. Tingkah laku tersebut berupa tingkah laku yang tampak maupun tidak tampak, tingkah laku yang disadari maupun yang tidak disadari (Sarwoto Sarlito Wirawan; 2009, hal. 4).

Psikologi Seni adalah bagian dari ilmu psikologi yang memfokuskan diri pada pertanyaan-pertanyaan yang berkaitan dengan para pendukung dalam proses artistik yaitu seniman, pengamat dan kritikus. Di antara ketiganya, peran seniman dan pengamat mendapat perhatian besar. Seorang psikolog seni terutama tertarik pada proses-proses psikologis yang memungkinkan penciptaan dan tanggapan terhadap seni. 


\section{Metode}

Pada karya-karya yang diciptakan dipilih teknik cetak saring atau sablon di atas kertas. Pemilihan teknik ini sangat mampu mencapai garis-garis detail dan blok warna yang diinginkan, serta dapat mentransfer langsung gambar tangan ke dalam screen. Gambar yang tentu saja memiliki sentuhan dari perasaan seniman ketika menggambar secara langsung. Teknik silk screen ini seniman pilih selain karena bisa menghasilkan dengan jumlah yang banyak, kwalitas film yang bisa dikatakan baik, adapun hasil cetakan juga relatif stabil. Selain itu seniman lebih banyak menggunakan simbol-simbol sebagai bentuk makna personal yang seniman yakini. Permainan garis, komposisi, warna dan tekstur juga seniman pakai sebagai bagian dari uraian cerita yang seniman buat pada karya-karya yang diciptakan.

Berikut akan diuraikan beberapa elemen yang terkandung dalam konsep bentuk/perwujudan:

\section{Garis}

Pilihan garis yang digunakan adalah sebagai pemisah bentuk satu dengan yang lain. Garis yang tercipta dari adanya perbedaan warna. Setiap garis yang digunakan menimbukan kesan psikologis dan persepsi tersendiri. Misalnya garis "S" sering dirasa sebagai sesuatu yang lembut dibandingkan dengan garis berbentuk "Z" yang terkesan tegas dan kaku. Hal ini disebabkan karena ingatan kita akan bentuk lekuk tubuh atau ombak. Selain garis sebagai pembentuk kontur, garis merupakan bagian dari elementer untuk mengungkapkan gerak dan bentuk, baik bentuk dua dimensi maupun tiga dimensi. Garis memiliki kemampuan untuk mengungkapkan suasana, seniman menciptakan sebuah garis yang terjadi karena proses stimulasi dari bentuk-bentuk sederhana yang sering seniman amati.

Lebih jauh lagi garis sesuai dengan fungsinya yang khas, mampu membentuk simbol yang memiliki pengertian khusus. Penggunaan garis sebagai simbol pertama kali diperkenalkan oleh Otto Neurath (1882 - 1945) seorang pengajar dan ilmuwan sosial, yang menamakan simbol sebagai Isotype, dan berkembang dan menjadi salah satu bahasa gambar yang mempu mewakili berbagai bentuk komunikasi. 


\section{Simbol}

Kata Simbol berasal dari kata symballo yang berasal dari bahasa Yunani. Symballo artinya "melempar bersama-sama", melempar atau meletakkan bersama-sama dalam satu ide atau konsep objek yang kelihatan, sehingga objek tersebut mewakili gagasan. Simbol dapat menghantarkan seseorang ke dalam gagasan atau konsep masa depan maupun masa lalu. Simbol adalah gambar yang digunakan untuk mendukung teks, membuat makna yang lebih jelas dan lebih mudah dipahami (Joko Warino) Simbol yang seniman tampilkan pada karya memiliki latar belakang pengalaman yang pernah dialami, dan memiliki arti atau makna personal, baik secara spiritual maupun teori-teori yang seniman dapatkan melalui beberapa sumber.

Berikut adalah beberapa contoh inspirasi simbol yang memiliki arti khusus bagi seniman:

- $\quad$ Simbol hati (Jantung)

Pada Zaman dulu, para Sumerian Assyrian menganggap manusia berpikir dan berperasaan menggunakan organ hati (liver). Tetapi hal ini dibantah oleh Aristoteles yang beranggapan bahwa untuk berpikir dan berperasaan, manusia menggunakan jantung (dalam Erbe Sentanu; 2007, hal. 121). Di Indonesia heart yang dimaksudkan adalah hati tetapi melalui terjemahan heart adalah jantung. Hati dalam konteks pemaknaan seniman adalah cinta dan merupakan pusat dari kehidupan (keluarga).

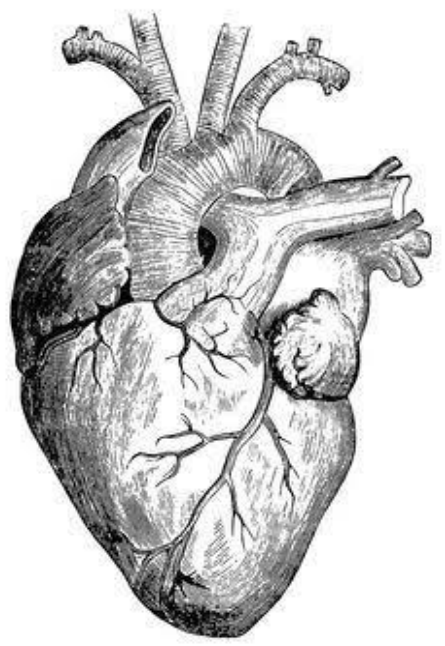

Gambar 1. Jantung manusia (Sumber : https://www.pinterest.com/pin/2226467755301251 
- $\quad$ Simbol Piala Anggur dan Sibori

Simbol ini mewakili sebuah liturgi ekaristi dalam misa agama katolik. Liturgi ini juga merupakan bagian penting di dalam misa, dan juga peristiwa penting juga bagi seniman. Hal ini dikarenakan, ketika seniman menerima hosti, seniman seakan telah bersatu bersama pencipta (konteks keimanan).

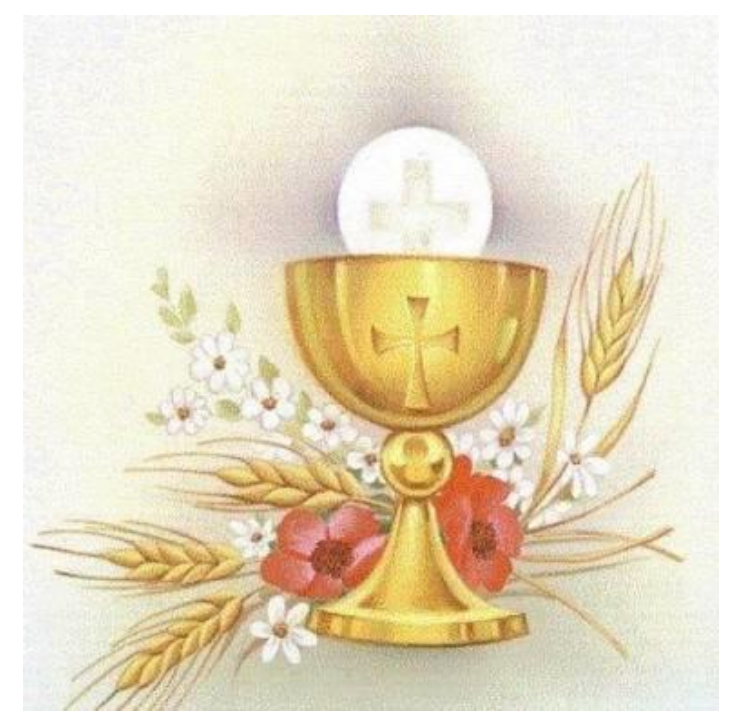

Gambar 2. Piala Hosti

(Sumber : gerejak.blogspot.co.id https://www.google.co.id/search?awan-vector (diakses pada tanggal 22 Januari 2017, jam 10.15 WIB)

\section{- $\quad$ Simbol PX}

Biasa terdapat pada gereja katolik PX sebagai tanda resmi untuk menandakan Kristus. Lambang ini diambil dari dua huruf pertama Yunani yaitu “CRISTOS”yang berbunyi Christos atau Kristus.

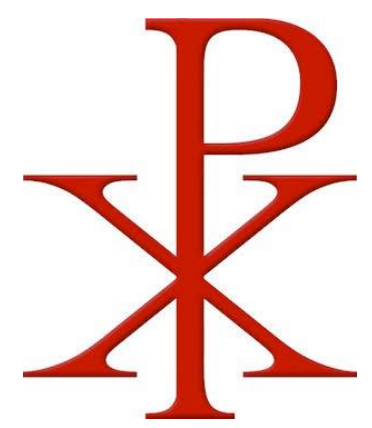

Gambar 3. Lambang PX pada gereja Katolik

(Sumber : https://www.google.co.id/search?awan-vector (diakses pada tanggal 22 Januari 2017, jam 18.00 WIB) 


\section{- $\quad$ Simbol Alfa dan Omega}

Lambang ini sering ditemui pada lilin paskah atau kasula (jubah) yang dipakai Romo. Abjad Yunani, Alfa (A) dan Omega (O) huruf pertama dan terakhir yang dipakai mewakili artian awal dan akhir dan melambangkan Allah sebagai awal dan akhir asal dan tujuan kita. Seperti kehidupan dan kematian.

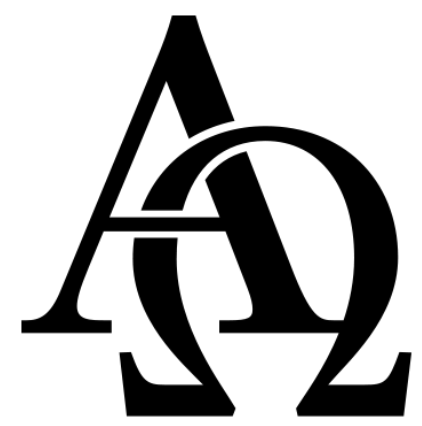

Gambar 4. Alfa dan Omega (Sumber : mudikans.mudikaic.org/2012/01/lambang-gereja)

\section{Bentuk}

Selain simbol yang telah disebutkan di atas, seniman juga menggunakan bentuk-bentuk figuratif yang telah mengalami proses deformasi sebagai perwakilan dari inspirasi bentuk-bentuk manusia dan lain sebagainya. Deformasi adalah perubahan susunan bentuk yang sangat kuat/besar sehingga kadang-kadang tidak lagi berwujud figur semula atau wujud sebenarnya. Sehingga hal ini dapat memunculkan figur/karakter baru yang lain dari sebelumnya (Mikke Susanto; 2002, hal. 30). Seniman memilih bentuk figuratif karena dapat menggambarkan bentuk yang biasa dikenal sebagai objek-objek alami, manusia, tumbuhan, hewan, gunung, laut, sungai dan benda-benda mati lainnya yang seniman gambarkan dengan cara meniru rupa serta warna benda- benda tersebut. Bentuknya tidak meniru rupa sesungguhnya, tetapi dirubah untuk kepentingan pemaknaan, misalnya, bentuk tubuh manusia yang diperpanjangan dan lain-lain. Bentuk deformasi dilakukuan dengan tujuan untuk mengubah atau memisahkankan bagian bentuk demi mencapai keinginan visual yang seniman harapkan tetapi tidak meninggalkan keselarasaan maknanya. 


\section{Warna}

Warna memiliki peranan penting bagi manusia dan seni sebagai elemen estetika, representasi dari alam, alat atau sarana media komunikasi (fungsi representasi). Pada tahun 1858, Munsell menyelidiki warna dengan standar warna untuk aspek fisik dan psikis. Pada umumnya pemahaman warna dan maknanya berbeda tergantung pada budaya, ideologi dan agama suatu tempat. Dibeberapa situasi setiap negara dapat memiliki makna warna yang berbeda. Warna mampu memberikan kesan dan identitas tertentu pada sebuah gambar dan bentuk. Warna-warna yang seniman gunakan kebanyakan berasal dari referensi alam, seperti warna api dan air dan memiliki arti psikologis personal. Warna pada simbol religi dan mitos juga ditampilkan dalam karya yang dibuat juga warna yang berkaitan dengan ingatan seniman akan beberapa memori.

\section{Komposisi}

Komposisi yang ditampilkan pada karya memiliki satu pusat perhatian (fokus) dan memiliki keseimbangan unsur-unsur simbol dan bentuk lain di dalamnya. Seniman banyak menampilkan visual komposisi yang terkesan seimbang baik simetris maupun asimetris dengan jumlah elemen bentuk yang berbeda-beda. Keseimbangan pada karya juga diatur oleh proporsi objek utama pada gambar berupa pengaturan ukuran besar dan kecilnya agar lebih menonjol (centre of interest). Selain itu keserasian dan komposisi juga dipikirkan dengan matang, perpaduan unsur rupa yang selaras dan berhubungan, tidak bertentangan satu dengan yang lain melalui perpaduan warna.

Pengulangan bentuk dan tatanan gambar pada karya akan menimbulkan kesan gerak (irama) bagi orang yang melihatnya. Kesan gerak yang dibuat misa monotan (sama) baik dari segi ukuran, warna maupun jarak. Atau juga kesan irama yang ditata selang seling baik dari segi bentuk, warna dan ukuran.

\section{Ruang}

Seniman membuat karya dua dimensi, dimana ruang dapat mengacu pada luas bidang gambar. Unsur ruang dua dimensi bersifat semu akibat kesan 
penggambaran yang seniman tampilkan yakni melalui penggunaan perspektif, peralihan warna, gelap terang dan tekstur.

\title{
7. Tekstur
}

Tekstur yang dibuat terdiri dari tekstur kasar lembut, halus, kasar, berpori dan sebagainya, hal ini mewakili sifat simbol atau benda yang ditampilkan pada karya

\section{HASIL PENCIPTAAN}

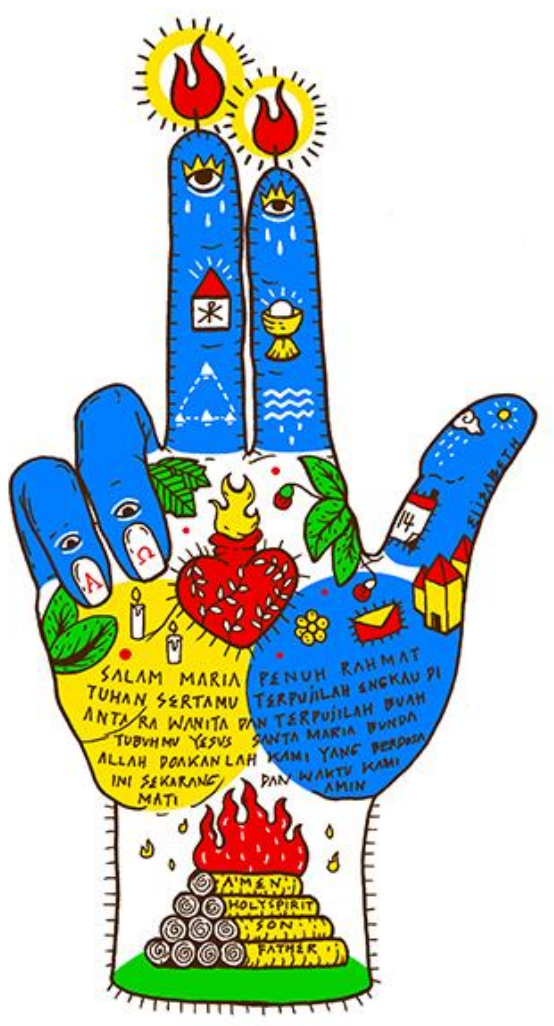

\author{
Gambar 5. \\ "Salam Maria (Mother in Heaven)" \\ Silk screen di atas kertas \\ $18,5 \mathrm{~cm}$ x $35 \mathrm{~cm}, 2016$ \\ (Foto: Bernadheta Dwi Puspitasari)
}

Objek utamanya adalah sebuah tangan dengan sikap "babtis" yang sering dilakukan oleh imam gereja Katolik dan beberapa pose atau bentuk tangan pada patung-patung Yesus Kristus. Bermakna personal sebagai wujud penyerahan diri kepada sang Ilahi, dalam hal ini yang seniman maksud adalah ibu yang meneripa Sakramen Minyak Suci sehari sebelum beliau meninggal. Sakramen Minyak Suci adalah salah satu dari tujuh sakremen pada agama katolik yang biasa lakukan pada orang-orang yang sedang sakit keras. Sakramen ini berupa pengurapan Minyak suci oleh Romo (Imam gereja Katolik) pada seseorang yang sakit keras.

Karya ini sarat akan makna rohani, pada bagian dalam tangan terdapat lafal doa penting dalam agama katolik, yakni "Salam Maria", sebagai perwakilan ungkapan doa kepada Sang Ibu (ibu seniman dan ibu Yesus Kristus). Simbolsimbol yang dipakai juga masih merupakan simbol gereja atau rohani, dan 
terdapat simbol alpha - omega yang berarti awal dan akhir atau kelahiran dan kematian. Sementara warna dominan biru memberi kesan kesejukan dan damai serta menenangkan pikiran, yang bermakna bahwa ibu sudah tenang/damai.

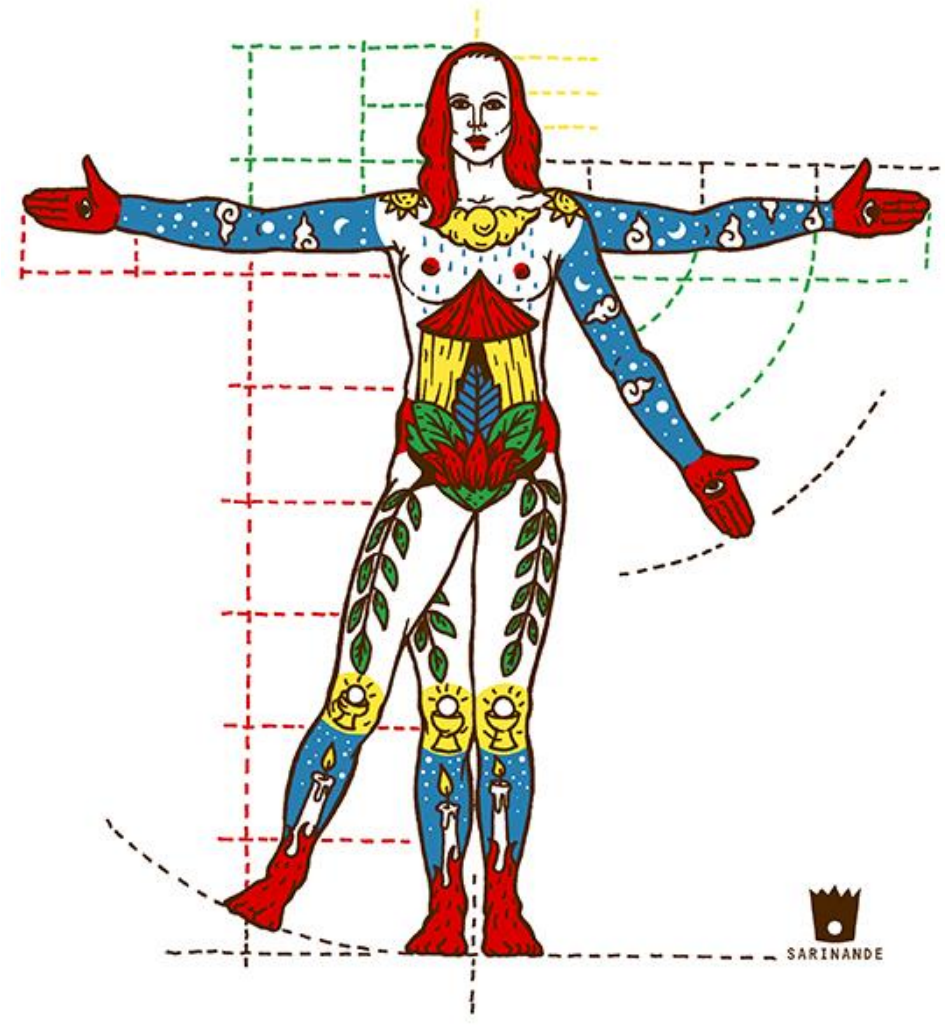

Gambar 6

"Matius $5: 15$ "

Silk screen di atas kertas

$26 \mathrm{~cm} \times 27,5 \mathrm{~cm}, 2016$

(Foto: Bernadheta Dwi Puspitasari)

Matius 5 : 15 adalah isi dari sebuah ayat di Alkitab yang berbunyi;

"lagipula orang tidak menyalakan pelita lalu meletakannya di bawah gantang, melainkan di atas kaki dian sehingga menerangi semua orang di dalam rumah itu".

Ayat di atas dimaknai seniman sebagai seorang manusia adalah pelita bagi keluarganya, khususnya bagi orang tuanya. Gambar seorang perempuan terinspirasi dari gambar anatomi tubuh oleh Leonardo Da Vinci, yang mewakili makna bahwa manusia dirancang dan digambarkan oleh Tuhan untuk menjadi pelita bagi orang tua, keluarga dan sesamanya (menjadi manusia yang berguna). Simbol yang dipakai masih berhubungan dengan simbol gereja Katolik dan bermakna religius. 
Pada bagian perut terdapat bentuk rumah dan bunga yang subur artinya bahwa sosok itu bukan hanya perempuan tetapi juga sebagai ibu. Warna-warna yang dipakai adalah perwakilan dari makna semangat (merah), cinta (merah), kedamaian (biru), sebuah tempat yang luas (biru), cahaya (sinar) kegembiraan (kuning), dan harmoni/menenangkan (hijau). Sementara garis putus-putus pada gamabar memiliki arti garis bantu (sketsa) untuk mewujudkan hasil yang sempurna dan baik.

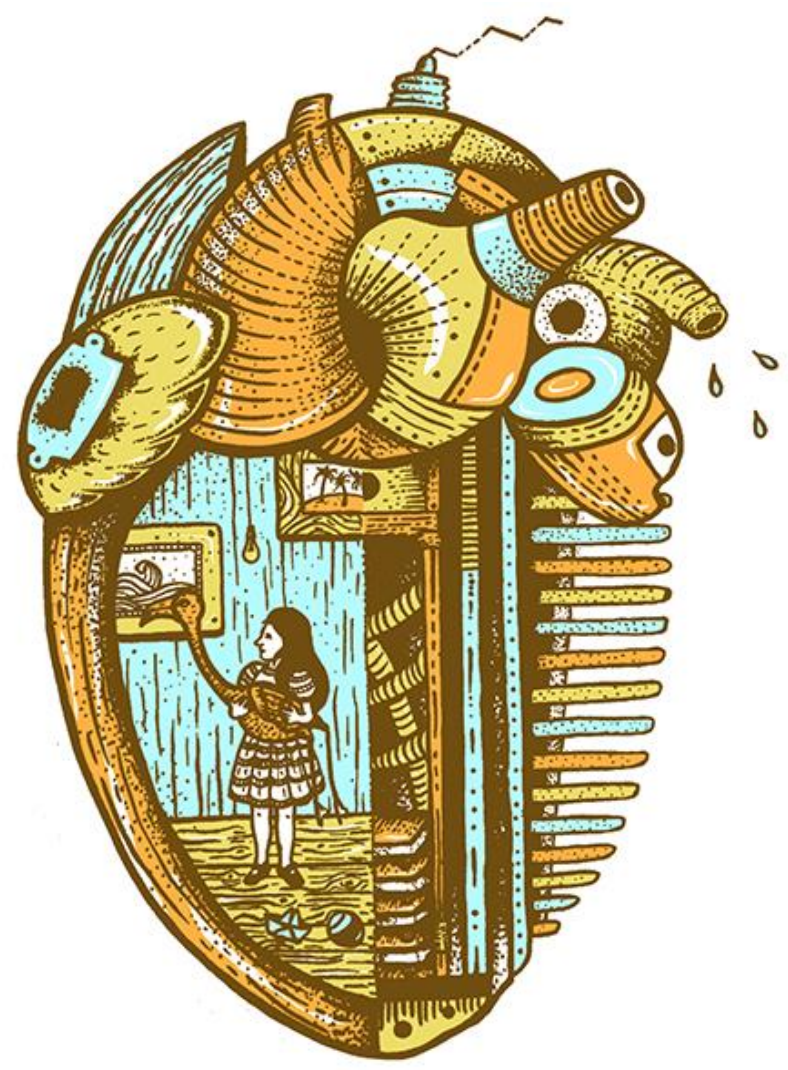

Gambar 7.

"Mesin Hati"

Silk screen di atas kertas

$25,5 \mathrm{~cm} \mathrm{x} 35 \mathrm{~cm}, 2017$

(Foto: Bernadheta Dwi Puspitasari)

Pada gambar ini dibuat dua sisi yang berbeda namun dari bentuk yang sama, yaitu bentuk hari dan mesin berbentuk hati. Hati yang berbentuk setengah mesin bermakna bahwa terkadang manusia berlaku seperti robot yang memiliki mesin penggerak yang tanpa sadar melakukan aktivitas sama berulang kali. Hal ini seperti perasaan manusia, yang memiliki sifat penyangkalan terhadap sesuatu yang menurutnya pahit. Lalu agar hidupnya seperti berjalan biasa saja, makan ia bersikap seperti robot yang memiliki sistem seting didalamnya. 
Pada sisi lain terdapat seorang anak perempuan yang sedang mengangkat seekor burung Flaminggo. Sosok anak perempuan ini bermakna berapapun usia kita, berapapun ukuran tubuh kita, anak tetaplah anak-anak manis bagi orang tuanya, sedangkan latar belakangnya seniman gambarkan seperti ruangan keluarga yang berarti rumah.

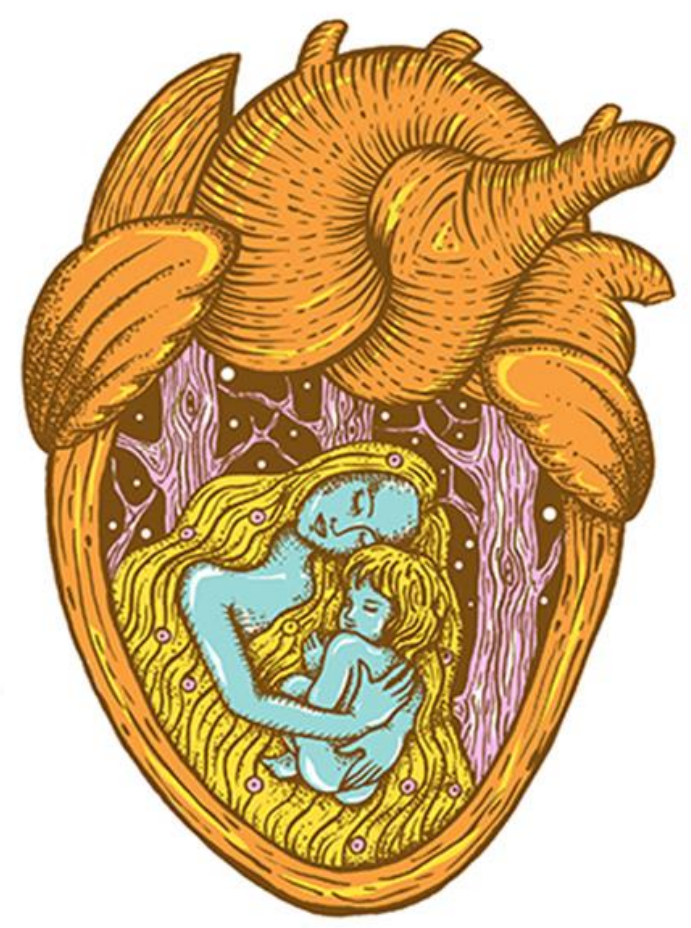

Gambar 8.

"Nina Bobo"

Silk screen di atas kertas

$25 \mathrm{~cm}$ x $34 \mathrm{~cm}, 2017$

(Foto: Bernadheta Dwi Puspitasari)

Bentuk hati adalah melambangkan isi hati yang meenggambarkan sosok perempuan (ibu) yang sedang memeluk anaknya. Karya ini merupakan ungkapan kejujuran yang seniman rasakan, sebuah rasa yang ingin terus dilindungi dan dicintai oleh ibunya, dan sebagai seorang ibu ingin melindungi anaknya hingga kapanpun. Nuansa latar belakang malam bermakna interaksi ibu ketika anaknya hendak tidur, dalam suasana yang tenang dan nyaman. Warna oranye pada bentuk hati melambangkan sebuah rasa hubungan yang erat, optimis dan rasa ceria (bahagia). 


\section{SIMPULAN}

Rindu kepada ibu menjadi sebuah alasan mengapa selama ini dari kebanyakan karya yang diciptakan bermakna personal dan berhubungan dengan psikologi seniman. Beberapa karya yang diciptakan secara sengaja atau mengalir begitu saja ternyata mampu menghadirkan simbol-simbol perempuan dan simbol spiritual yang seniman yakini. Baik ada kaitannya dengan memori bahagia tentang ibu maupun peristiwa-peristiwa duka saat meninggalnya ibu. Hal ini seperti bentuk terapi yang berulang kali dijalani seniman, karena perasaan yang timbul setelah itu adalah perasaan lega yang seakan-akan beban di hati sedikit terobati.

Teknik silk screen dipilih sebagai teknik yang mampu menghadirkan gambaran original yang seniman buat sebelum pada buku sketsa. Garis dan bentuk dapat sama persis di transfer ke dalam bentuk film, yang kemudian dicetak dengan hasil yang sama persis dengan bentuk dan warna yang seniman buat pada gambar sketsa. Teknik silk screen dirasa mempu melanjutkan manifestasi perasaan serta emosi yang dituangkan dalam sebuah sketsa manual menjadi sebuah karya seni grafis. Tetapi seniman yakin bahwa karya yang dibuat sebagai menifestasi rasa rindu kepada ibu ini tidak berhenti sampai di sini. Selama masih hidup seniman pasti akan merindukan ibu dan kerinduan itu akan menjadi alasan untuk berkarya serta menjadikan kegiatan berkarya tersebut sebagai terapi seni bagi seniman sendiri.

Seni sebagai alat terapi untuk menciptakan karya bertema menifestasi rasa rindu kepada ibu ini seniman anggap berhasil, tolak ukurnya adalah secara psikologis seniman lebih merasa lega dan tenang, karena mampu memindahkan isi kepala dan perasaan hati seniman ke dalam sebuah bentuk fisik karya yang biasa seniman nilai dan rasakan sendiri. melalui terapi ini pula, sebagian dari sikap seniman yang selama ini tertutup pada keluarga saat ini bisa lebih terbuka. Walau memang tidak total dapat mengobati dampak dari kehilangan ibu, tetapi seniman yakin melalui terapi seni ini, akan mampu menjadi jalan dan solusi bagi masalah psikologi seniman dikemudian hari. 


\section{DAFTAR PUSTAKA}

Effendy. Dasar-dasar Kepewatan Kesehatan Masyarakat. Jakarta. EGC, 2004.

Ellen Winner. Invented World: The Psychology of the Art, Harvard University Press, 1982.

Erbe Sentanu. Quantum Iklas: Teknologi aktivitas dan kekuatan hati. Alex Media Komputindo. Jakarta, 2007.

Irma Damajanti. Psikologi Seni, PT Kiblat Buku Utama, Bandung, 2006.

Lemme, B. H. Development in Adulthood. USA: Allyn \& Bacon, 1995.

M. Dwi Marianto. ART \& LEVITATION:Seni dalam Cakrawala Quantum. Penerbit: Pohon Cahaya, Yogyakarta, 2015.

Mike Susanto,. Diksi Rupa: Kumpulan Istilah Seni Rupa. Yogyakarta. Penerbit: Kanisius, 2002.

Papalia, D. E, Olds, S. W. \& Feldman. Human Development Psikologi Perkembangan (9th ed). Jakarta: Kencana, 2008.

Santrock, J. W. Life-Span Development Perkembangan Masa Hidup (5th ed). Jakarta: Erlangga, 2004.

Sarwono, Sarlito Wirawan. Pengantar Psikologi Umum. Rajawali, Jakarta, Press, 2009.

Sarwono, S. W. Psikologi Remaja. Jakarta: PT Raja Grafindo Persada, 2004.

Sarwono, Sarlito Wirawan. Pengantar Psikologi Umum. Rajawali, Jakarta, Press, 2009.

Stewart, C. A, Perlmutter, M. Friedman, S. Lifelong Human Development. USA: Willey, 1988.

Suryani, Eko dan Hesti Widyasih. Psikologi Ibu dan Anak. Penerbit:Fitramaya, Yogyakarta, 2001.

Yuliawati, Livia, J. L. Setiawan \& T.W. Mulia. Perubahan Pada Remaja Tanpa Ayah. Arkhe Th. 12/No.1/2007. 2007. 